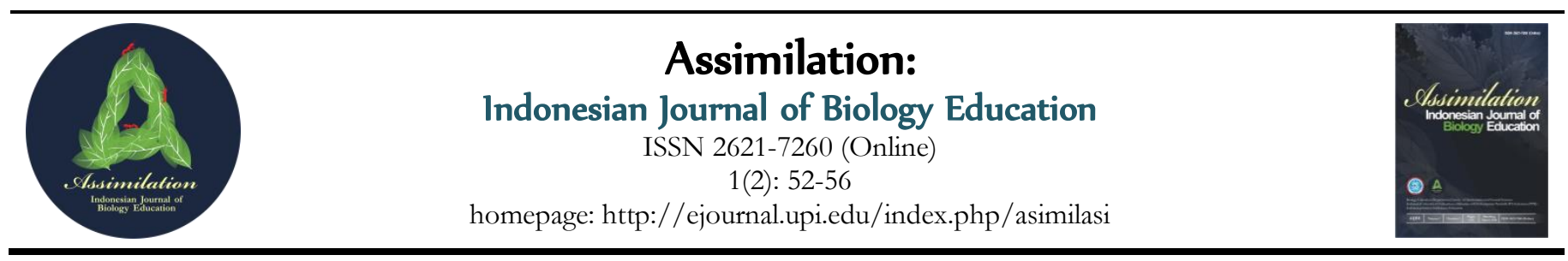

\title{
Penerapan Model Project Based Learning (PjBL) Bermuatan Nilai dalam Materi Sistem Ekskresi Manusia untuk Meningkatkan Hasil Belajar Siswa SMA (The Implementation of Value-Based Project Based Learning (PjBL) Model in Human Excretion System Concept to Increase Students Learning Outcomes)
}

\author{
Esri Desriyani*, Suroso Adi Yudianto, Bambang Supriatno \\ Departemen Pendidikan Biologi FPMIPA Universitas Pendidikan Indonesia, Jl. Dr. Setiabudhi No. 229 Bandung, Indonesia \\ *Corresponding author: esri.desriyani@gmail.com
}

Accepted: 16 September 2018 - Approved: 26 September 2018 - Published: 30 September 2018

\begin{abstract}
The aim of this research was to obtain the implementation of value-based Project Based Learning (PjBL) model toward high students learning outcomes. This research was implemented at high students with 35 people that took the purposive sampling. The Research method used weak experiment with one group pretest-posttest design. The result showed that student's ability of concepts showed well with $62,85 \%$ students passed and gain index of 52,2 \% (sufficient The level of student acceptance of science scores is included in the high category and the gain index reaches $11 \%$ (low). Students' attitude based on observation results has a value of 3.75 (very good). The results of the questionnaire processing show that all students experience problems during learning, especially when designing projects. The results of calculations with the t-test show that the Project Based Learning Value Model influences the mastery of students' concepts and attitudes. The results of calculations with Spearman correlation show that there is a positive relationship with a low category $(r=0.2)$ between mastery of concepts with students' attitudes towards the acceptance of science values.
\end{abstract}

Keywords Project Based Learning (PjBL), attituded of student, value based learning, students learning outcomes

\begin{abstract}
ABSTRAK Penelitian ini bertujuan untuk mengetahui penerapan model Project Based Learning (PjBL) Bermuatan Nilai terhadap hasil belajar siswa. Penelitian ini dilakukan terhadap siswa kelas XI IPA sebanyak 35 orang dengan pengambilan sampel secara purposive sampling. Metode yang digunakan adalah weak experiment dengan desain penelitian one group pretest-posttest design. Hasil penelitian menunjukkan bahwa kemampuan penguasaan konsep siswa berada dalam kategori baik dengan persentase ketuntasan 62,85\% dan indeks gain mencapai 52,2\% (sedang). Tingkat penerimaan siswa terhadap nilai sains termasuk pada kategori tinggi dan indeks gain mencapai 11\% (rendah). Sikap siswa berdasarkan hasil observasi memiliki nilai 3,75 (sangat baik). Hasil pengolahan angket menunjukkan bahwa seluruh siswa mengalami kendala selama pembelajaran terutama saat merancang proyek. Hasil perhitungan dengan uji t' menunjukkan bahwa model Project Based Learning Bermuatan Nilai berpengaruh terhadap penguasaan konsep dan sikap siswa. Hasil perhitungan dengan korelasi Spearman menunjukkan bahwa terdapat hubungan positif dengan kategori rendah $(\mathrm{r}=0,2)$ antara penguasaan konsep dengan sikap siswa terhadap penerimaan nilai sains.
\end{abstract}

Kata kunci Model Project Based Learning (PjBL), sikap siswa, pembelajaran muatan nilai, hasil belajar

\section{PENDAHULUAN}

Belajar merupakan aktivitas yang dilakukan seseorang untuk mendapatkan perubahan dalam dirinya melalui pelatihan atau pengalaman-pengalaman. Interaksi dalam proses belajar mengajar tidak hanya penyampaian materi pelajaran melainkan harus menanamkan sikap dan nilai pada diri siswa yang sedang belajar (Rustaman, 2005). Oleh karena itu, seorang pendidik harus dapat menanamkan sistem nilai dan moral guna meningkatkan keimanan dan ketakwaan peserta didik terhadap Tuhan Yang Maha Esa. Salah satu caranya adalah mengingatkan peserta didik untuk tidak hanya menguasai pengetahuan semata, melainkan dibiasakan untuk menghayati setiap bahan ajar sehingga peserta didik dapat bersyukur kepada Allah dan memiliki karakter bangsa yang diharapkan.

Seorang pendidik perlu mewaspadai terhadap pesatnya perkembangan teknologi yang dapat mengubah karakter peserta didik. Kini peserta didik dihadapi dengan generasi yang lahir pada era tersebut (generasi Z). Berdasarkan pengelompokkan generasi yang dikemukakan Strauss, generasi Z memiliki karakteristik cenderung berkurang dalam komunikasi secara verbal, cenderung bersikap egosentris, individualis, cenderung menginginkan hasil yang serba cepat, serba mudah, dan tidak menghargai proses (Andrianto, dalam Nugraha 2013). Sehingga, untuk menghadapi generasi tersebut, diperlukan model pembelajaran yang dapat meningkatkan penguasaan 
konsep siswa, memberikan penguatan serta meningkatkan sikap siswa ke arah yang lebih baik seperti religius, saling menghormati, mampu bersosialisasi, kritis, disiplin, menghargai orang lain dan mampu bekerjasama sebagaimana tujuan kurikulum pendidikan saat ini untuk menghasilkan insan Indonesia yang produktif, kreatif, inovatif, afektif melalui penguatan sikap, keterampilan dan pengetahuan yang terintegrasi (Kemendikbud, 2013). Sikap seseorang dibentuk oleh informasi yang diperolehnya. Informasi tersebut dapat diperoleh dari kajian penggalian nilai-nilai yang dikandung oleh bahan ajar sains (Yudianto, 2008). Oleh karena itu penggalian nilai-nilai sains perlu diperkenalkan kepada peserta didik melalui pembelajaran bermuatan nilai atau bernuansa imtak.

Project Based Learning memiliki potensi yang besar untuk memberi pengalaman belajar yang lebih menarik dan bermakna bagi siswa. Melalui pembelajaran $\mathrm{PjBL}$ siswa terlibat dalam investigasi pemecahan masalah, kegiatan tugas-tugas bermakna, dan bekerja secara otonom dalam mengkontruksi pengetahuan mereka sendiri (Thomas, 1999 dalam Wena, 2000). Dalam mewujudkan generasi yang produktif, kreatif dan aktif bersosialisasi, pembelajaran dengan model PjBL sangat dibutuhkan, dan untuk merubah sikap atau memberikan penguatan untuk bersikap positif maka pembelajaran bermuatan nilai sangat diperlukan. Maka dari itu model PjBL bermuatan nilai perlu diteliti. Model PjBL bermuatan nilai yang diteliti ini memiliki sintak yang terdiri dari: starts with the essential question, design a plan for the project, creates a schedule, monitor the students and the progress of the project, assess the outcome, dan evaluate the experiences. Dalam setiap tahapannya diikuti dengan kegitan menghayati bahan ajar guna menggali dan mengungkapkan nilai sains yang dikandungnya.

\section{METODE}

Metode yang digunakan dalam penelitian ini adalah weak eksperimental dengan desain penelitian yang digunakan adalah the one grup pretest and posttest. Populasi penelitian ini adalah seluruh siswa kelas XI semester genap, tahun ajaran 2013-2014 di salah satu SMAN di Cimahi. Adapun sampel penelitian ini adalah siswa satu kelas yang berjumlah 35 siswa dengan teknik pengambilan sampel secara purposive sampling. Instrumen yang digunakan dalam penelitian ini adalah tes penguasaan konsep berjumlah 20 soal yang terdiri dari 18 soal pilihan ganda dan 2 soal uraian terbatas, lembar observasi sikap siswa yang bertujuan untuk menilai sikap siswa selama proses pembelajaran, angket skala sikap model Likert dengan empat pilihan jawaban dengan jumlah 18 butir pernyataan yang terdiri dari sembilan pernyataan positif dan sembilan pernyataan negatif dan angket respon siswa untuk mengetahui kendala yang dialami siswa selama pembelajaran.

Data dari tes penguasaan konsep selanjutnya dianalisis dengan mencari nilai $N$-gain, menghitung persentase ketuntasan belajar (KKM). Data dari jawaban angket skala sikap siswa dianalisis dengan cara menghitung persentase penerimaan siswa terhadap masing-masing nilai sains kemudian dihitung nilai $\mathrm{N}$-gain dan dilakukan uji t' untuk mengetahui ada tidaknya pengaruh model pembelajaran PjBL bermuatan nilai terhadap sikap siswa. Data hasil observasi yang telah didapat selanjutnya dianalisis dengan cara menghitung rata-rata skor setiap sikap yang diobservasi yang selanjutnya skor tersebut dikonversi berdasarkan Permendikbud No. 81 A tahun 2013. Untuk mengetahui korelasi antara penguasaan konsep dan sikap siswa dilakukan uji hipotesis menggunakan Korelasi Spearman Rank, sedangkan untuk mengetahui kendala siswa selama pembelajaran dilihat berdasarkan persentase dari masing-masing kendala.

\section{HASIL DAN PEMBAHASAN}

\section{Penguasaan Konsep Siswa}

Penguasaan konsep siswa sebagai hasil belajar siswa ditunjukan pada Tabel 1 dibawah ini.

Tabel 1. Perbandingan Nilai Pretest Dan Posttest Penguasaan Konsep Siswa

\begin{tabular}{lcc}
\hline Komponen & Pretest & Posttest \\
\hline Nilai rata-rata & 38 & 70,4 \\
Nilai tertinggi & 66 & 84 \\
Nilai terendah & 16 & 44 \\
N-gain & & 0,522 \\
\hline
\end{tabular}

Pada Tabel 1 menunjukkan bahwa nilai rata-rata posttest lebih tinggi dari pada nilai rata-rata pretest $(70,4>$ 38). Peningkatan penguasaan konsep siswa tersebut selanjutnya dilihat kategori peningkatan rata-rata umumnya dengan $N$-gain ternyata memiliki indeks gain sebesar 0,522 yang termasuk dalam kategori sedang. Selanjutnya penguasaan konsep siswa dikategorisasikan berdasarkan kategori hasil belajar (Gambar 1).

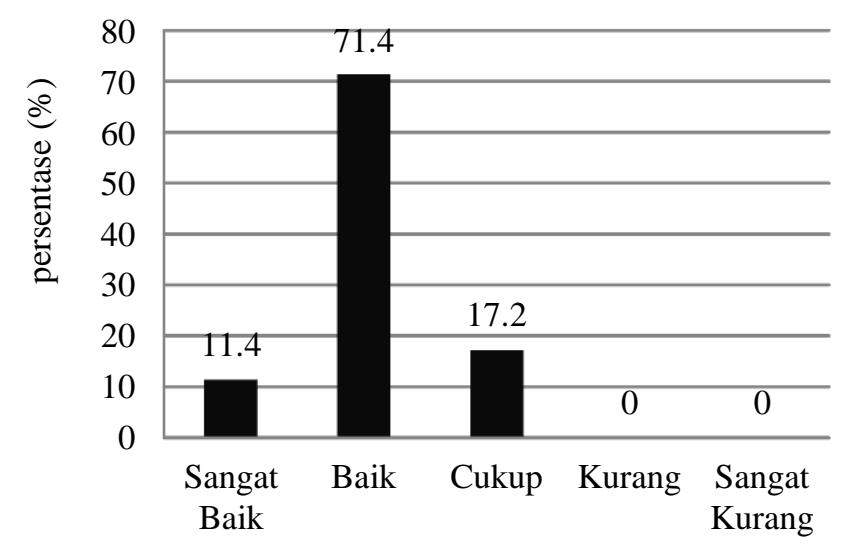

Gambar 1. Persentase Kategorisasi Penguasaan Konsep Siswa

Berdasarkan Gambar 1, penguasaan konsep siswa setelah pembelajaran terdiri dari tiga kategori, yaitu kategori sangat baik sebanyak $11,4 \%$, baik $71,4 \%$ dan cukup $17,2 \%$ sedangkan berdasarkan hasil perhitungan, rata-rata penguasaan konsep siswa termasuk dalam kategori baik. Apabila dibandingkan dengan kriteria ketuntasan minimal (KKM) siswa yang tuntas diatas nilai KKM dapat dilihat pada Gambar 2.

Selama pembelajaran dengan model PjBL bermuatan nilai siswa dibiasakan untuk menggali kandungan nilai sains dalam materi sistem ekskresi. Untuk menggali 
kandungan nilai sains siswa harus menghayati bahan ajar dan memahami konsep (nilai praktis) terlebih dahulu. Kemudian untuk mengerjakan proyek siswa harus dapat bersosialisasi dengan orang lain untuk membangun pengetahuannya, sehingga pada tahap inilah terjadinya peningkatan penguasaan konsep siswa. Sebagaimana menurut Vigotsky salah satu konsep dasar pembelajaran ini adalah adanya interaksi sosial individu dengan lingkungannya (Elliot, 2003 dalam Baharudin 2007). Selain daripada itu Model PjBL ini termasuk pada konsep belajar kontruktivisme (Wena, 2008).

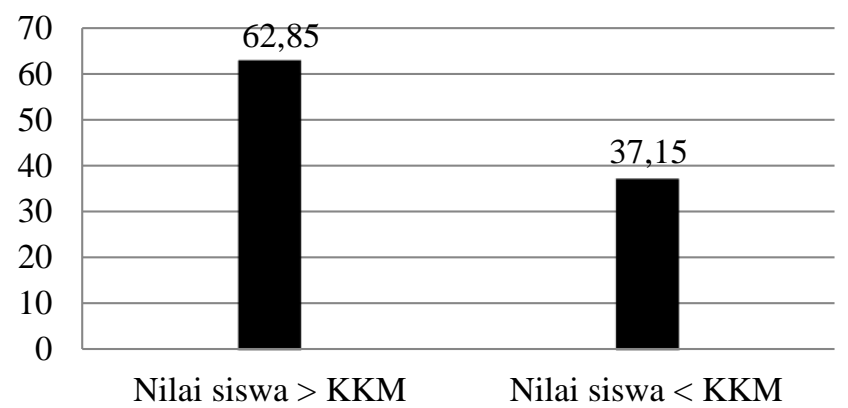

Gambar 2. Persentase Ketuntasan Siswa Berdasarkan KKM

Dalam penelitian ini peningkatan penguasaan konsep siswa termasuk kategori sedang, hal ini disebabkan karena peningkatan penguasaan konsep sebagai hasil belajar dapat dipengaruhi oleh beberapa faktor diantaranya kesiapan belajar, intelegensi, perhatian dan motif. Kesiapan siswa dapat mempengaruhi hasil belajar siswa, jika siswa sudah memiliki kesiapan pada saat akan dilaksanakan pembelajaran, maka hasil belajar yang didapatkannya juga akan lebih baik (Slameto, 2003). Berdasarkan hasil observasi, masih terdapat beberapa siswa yang kurang siap untuk belajar dikarenakan pelajaran biologi berada pada jam terakhir dan dimulai setelah siswa selesai istirahat kedua, ketidaksiapan tersebut berawal dari ketidaktepatan siswa masuk kelas. Faktor lainnya yang mempengaruhi hasil belajar ialah intelegensi dan perhatian. Intelegensi besar pengaruhnya terhadap kemajuan belajar. Siswa yang memiliki intelegensi yang tinggi akan lebih berhasil daripada siswa yang memiliki tingkat intelegensi yang rendah. Perhatian termasuk salah satu faktor dalam hasil belajar siswa karena apabila bahan pelajaran tidak menjadi perhatian siswa maka akan timbul kebosanan. Berdasarkan hasil observasi masih ditemukan beberapa siswa yang kurang perhatian pada saat kegiatan persentasi berlangsung. Project Based Learning bermuatan nilai ini dirancang dengan kegiatan pembelajaran yang menarik dan menjadi sarana siswa untuk berkreativitas sehingga siswa dapat terhindar dari kebosanan.

Faktor yang mempengaruhi hasil belajar selanjutnya ialah motif. Motif erat kaitannya dengan tujuan yang akan dicapai. Pada proses pembelajaran dengan model PjBL ini siswa memusatkan perhatiannya untuk menyelasaikan proyek hingga menghasilkan produk yang terbaik. Motif ini tentunya mempengaruhi peningkatan hasil belajar siswa sebagaimana dengan keuntungan pembelajaran model proyek based learning dapat meningkatkan motivasi belajar siswa menurut Morsound (1997) dalam Wena (2008).

\section{Sikap Siswa Terhadap Penerimaan Pengembangan Nilai-Nilai Sains}

Berdasarkan hasil penelitian menunjukkan bahwa penerimaan siswa terhadap kandungan nilai sains termasuk dalam kategori tinggi. Berikut ini adalah perbandingan penerimaan nilai sains dari masing-masing variabel nilai sains.

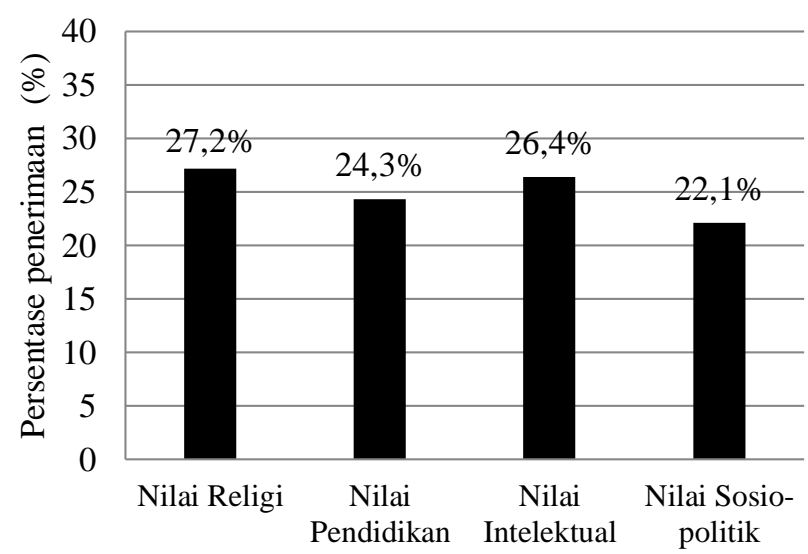

Gambar 3. Persentase Penerimaan Nilai Sains

Berdasarkan Gambar 3 diketahui bahwa tingkat penerimaan yang paling tinggi ialah penerimaan siswa terhadap kandungan nilai religi, hal ini disebabkan karena siswa sudah dibiasakan untuk mengaitkan materi biologi dengan keagungan Tuhan sedangkan tingkat penerimaan yang terendah ialah terhadap nilai sosio-politik hal ini disebabkan karena berdasarkan hasil wawancara menunjukkan bahwa siswa tidak begitu memahami soal politik dan menggali kandungan nilai politik merupakan hal yang baru bagi siswa. Selain daripada itu pretest skor siswa cenderung tinggi dan tingkat penerimaannya termasuk kategori tinggi pada umumnya. Sikap penerimaan terhadap kandungan nilai sains yang tinggi yang dimiliki siswa setelah pembelajaran, didukung oleh beberapa faktor seperti yang dikemukakan oleh Azwar (2010), di antaranya: pengalaman pribadi, kebudayaan, orang lain yang dianggap penting, media massa, institusi atau lembaga pendidikan serta faktor emosi dalam diri individu. Dalam penelitian ini tinjauan nilai belum sampai tatanan perilaku siswa, tetapi baru sebatas tatanan kognitif siswa, karena penelitian yang dilaksanakan dibatasi selama dua minggu. Penelitian mengenai sikap siswa terhadap penerimaan kandungan nilai sains ini didukung dengan hasil observasi sikap yang telah dilakukan, sehingga dalam penelitian ini penerapan model PjBL bermuatan nilai dapat meningkatkan sikap siswa untuk menerima kandungan nilai sains dalam materi sistem ekskresi.

\section{Sikap Siswa Berdasarkan Hasil Observasi}

Di samping menggunakan instrumen angket, untuk mengetahui sikap siswa pada saat pembelajaran dilakukan dengan cara observasi. Adapun hasil pengolahan data observasi maka didapatkan data sikap siswa disajikan pada Tabel 3. 
Tabel 3. Data Sikap Siswa Hasil Observasi

\begin{tabular}{llcc}
\hline $\begin{array}{c}\text { Pengembangan } \\
\text { nilai }\end{array}$ & \multicolumn{1}{c}{ Sikap } & Nilai & Kategori \\
\hline Nilai Religi & Religius & 3,5 & SB \\
Nilai Pendidikan & Kreatif & 3,75 & SB \\
Nilai Pendidikan & Rasa ingin tahu & 3,75 & SB \\
Nilai Intelektual & Disiplin & 3,25 & B \\
Nilai Intelektual & Adil & 3,75 & SB \\
Nilai Sosio-politik & Menghargai orang & 3 & B \\
& lain & & \\
Nilai Sosio-politik & Komunikatif & 3,75 & SB \\
Nilai Sosio-politik & Mampu & 3,75 & SB \\
& Bekerjasama & & \\
\hline \multicolumn{2}{c}{ Rata-rata nilai } & 3,56 & SB \\
\hline
\end{tabular}

Keterangan: SB (sangat baik); B (baik).

Berdasarkan data hasil observasi diketahui bahwa ratarata nilai sikap siswa ialah 3,5 (kategori baik). Kategori sangat baik ditunjukkan pada sikap religius, kreatif, rasa ingin tahu, adil dan mampu bekerja sama sedangkan kategori baik ditunjukkan pada sikap religius, disiplin dan menghargai orang lain. Rata-rata sikap yang menunjukkan kategori baik ini dapat dipengaruhi oleh beberapa faktor, salah satunya ialah faktor lingkungan. Siswa yang tidak aktif menjadi terbawa aktif sesuai dengan lingkungannya karena pembelajaran model PjBL ini mengarahkan siswa untuk bekerja secara kolaboratif. Sebagaimana menurut Slameto, sikap sebagai hasil belajar dipengaruhi juga oleh faktorfaktor eksternal seperti relasi guru dengan siswa, relasi siswa dengan siswa dan kehidupan dalam masyarakat (Slameto, 2003).

Pada kegiatan pembelajaran, siswa diberikan kesempatan untuk bersosialisasi dengan masyarakat, tentunya hal tersebut menunjang siswa untuk memunculkan sikap komunikatif. Selain dari pada itu, pembelajaran dengan model $\mathrm{PjBL}$ bermuatan nilai ini memberikan stimulus kepada siswa untuk berkreatif dan bekerjasama sebagaimana menurut Moursound (1997) dalam Wena (2008) pembelajaran berbasis proyek memiliki keuntungan yaitu siswa dapat mengembangkan dan mempraktikan keterampilan komunikasi dan kerjasama.

\section{Hubungan Penguasaan Konsep dan Sikap Siswa}

Hasil analisis korelasi menggunakan rumus Korelasi Spearman Rank menunjukkan bahwa terdapat hubungan antara penguasaan konsep dan sikap siswa. Adapun hasilnya sebagai berikut:

Tabel 4. Hubungan Penguasaan Konsep dengan Sikap Siswa

\begin{tabular}{cccc}
\hline Variabel X & Variabel Y & r & Keterangan \\
\hline $\begin{array}{c}\text { Penguasaan } \\
\text { konsep }\end{array}$ & Sikap Siswa & 0,2 & Rendah \\
\hline
\end{tabular}

Pada Tabel 4 diketahui bahwa terdapat korelasi dengan kategori lemah antara penguasaan konsep dan sikap siswa. Koefisien korelasi selanjutnya menguji hasil signifikasi korelasi dengan uji $\mathrm{t}$ menunjukkan bahwa terdapat hubungan antara penguasaan konsep dengan sikap siswa. Sebagaimana menurut Krech (1962) dalam Yudianto (2008) bahwa sikap seseorang dibentuk oleh informasi yang diperolehnya. Sikap siswa tersebut dapat dipengaruhi oleh faktor eksternal seperti lingkungan sosial, personalitas guru, media pembelajaran dan kurikulum yang ditetapkan oleh sekolah (Dimyati \& Mudjiono, 2009). Selain dari pada itu, faktor eksternal lainnya dapat berasal dari kondisi intrumen penelitian. Instrumen penelitian sebagai pengumpul data penelitian yang telah dilakukan termasuk dalam sampel kecil yaitu 50 orang. Idealnya untuk mengukur sikap manusia terhadap suatu konsep diperlukan sampel berukuran besar dengan jumlah minimal 200 orang reponden (Azwar, 2010). Butir tiap pernyataan juga dapat mempengaruhi siswa dalam mengisi angket. Butir pernyataan yang digunakan ini pada dasarnya belum sempurna dan diperlukan perbaikan kembali apabila akan digunakan untuk penelitian selanjutnya.

\section{Kendala Siswa Selama Pembelajaran}

Berdasarkan hasil analisis angket $100 \%$ (seluruh siswa) mengalami kendala selama melakukan pembelajaran. Data kendala yang dialami siswa selama pembelajaran ditunjukkan pada Tabel 5.

Tabel 5. Data Persentase Kendala yang Dialami Siswa Selama Pembelajaran

\begin{tabular}{clcl}
\hline No & \multicolumn{1}{c}{ Kegiatan } & $\begin{array}{c}\text { Persentase } \\
(\%)\end{array}$ & Kategori \\
\hline 1 & Merancang Proyek & 51,4 & $\begin{array}{l}\text { Sebagian } \\
\text { besar }\end{array}$ \\
2 & Mengerjakan Proyek & 42,8 & $\begin{array}{l}\text { Hampir } \\
\text { setengahnya }\end{array}$ \\
3 & Mempresentasikan & 22,8 & $\begin{array}{l}\text { Sebagian } \\
\text { kecil }\end{array}$ \\
& $\begin{array}{l}\text { Produk } \\
\text { Menggali Kandungan } \\
\text { Nilai Sains }\end{array}$ & 20 & $\begin{array}{l}\text { Sebagian } \\
\text { kecil }\end{array}$ \\
\hline
\end{tabular}

Kegiatan merancang proyek memiliki kendala paling tinggi yang dialami siswa. Hasil angket respon siswa menunjukkan bahwa kendala yang dialami siswa dalam merancang proyek ialah kendala dalam merumuskan masalah (31\%), kendala dalam membuat rancangan kerja $(48,6 \%)$ dan mengalami kendala dalam menentukan jadwal untuk mengerjakan proyek $(51,4 \%)$. Siswa mengalami kendala tertinggi dalam merancang proyek disebabkan karena siswa belum pernah belajar dengan model pembelajaran yang mengarahkan siswa untuk membuat rancangan. Dampaknya siswa juga mengalami keterlambatan dalam mengumpulkan rancangan proyek. Untuk mengatasi hal tersebut, selama pembelajaran siswa diarahkan untuk melakukan diskusi kelompok, sehingga dalam membuat rancangan tertampung banyak ide atau masukan dari beberapa siswa lainnya. Kendala berikutnya yang dialami siswa ialah kendala dalam mengerjakan proyek yang dialami oleh sebagian besar siswa $(42,8 \%)$. Berdasarkan hasil analsisis data diketahui bahwa kendala dalam tahap pengerjaan proyek adalah waktu yang tersedia untuk mengerjakan proyek kurang lama, hal tersebut dialami hanya oleh sebagian kecil siswa (32\%). Dalam penelitian ini siswa diberikan waktu selama 2 minggu untuk menyelesaikan proyek sebagaimana hasil kesepakatan bersama.

Kendala lainnya dalam tahap pelaksanaan adalah kendala yang dialami siswa dalam mencari referensi. 
Selama pembelajaran disekolah, siswa didukung dengan LKS namun tidak banyak siswa memiliki buku paket. Dalam mengantisipasi kendala tersebut, maka siswa diberikan kesempatan untuk menggunakan media elektronik baik HP maupun laptop untuk mencari referensi melalui dunia maya. Kesempatan ini tentunya menjadi hal yang bisa dimafaatkan untuk mengarahkan generasi Z untuk mengaplikasikan teknologi ke arah yang positif dan belajar sesuai dengan karakteristiknya. Anak generasi Z cenderung menyukai hal-hal yang bersifat aplikatif dan menyenangkan dan metode pembelajaran yang dikembangkan harus mampu mengakomodasi kecenderungan cara belajar yang mereka miliki sehingga pendekatan pembelajaran berpusatkan model sangat cocok untuk generasi tersebut (Iswadi, 2012).

Sulitnya mengolah informasi yang didapatkan dan keterbatasan biaya dalam mengerjakan produk juga menjadi kendala dalam mengerjakan proyek. Untuk mengantisipasi keterbatasan biaya bagi siswa maka sebaiknya produk yang akan dibuat harus dipertimbangkan dan disesuaikan dengan keadaan finansial peserta didik, namun akan lebih baik apabila guru membantu pendanaan atau melatih siswa untuk memanfaatkan bahan bekas untuk membuat produk.

Kegiatan mensosialisasikan produk merupakan kendala terendah yang dialami siswa yakni sebesar 9\% (3 orang siswa). Banyaknya siswa yang tidak mengalami kendala dapat disebabkan karena siswa memiliki motivasi untuk menyampaikan produknya. Kendala terakhir ialah kendala yang dialami siswa dalam kegiatan menggali kandungan nilai sains. Hanya sebagian kecil siswa saja yang mengalami kendala dalam menggali kandungan nilai sains. Berdasarkan hasil penelitian, sebagian kecil siswa menjawab mengalami kendala dalam menggali kandungan nilai sains. Hal ini disebabkan karena siswa tidak memahami nilai sains dan tidak memahami materi sistem Ekskresi. Ketidakpahaman terhadap materi ekskresi memiliki persentasi $20 \% \quad(7$ orang) sedangkan ketidak pahaman siswa terhadap nilai sains sebesar $17 \%$ atau setara dengan 6 orang siswa. Ketidakpahaman siswa terhadap materi sistem ekskresi dapat ditangani dengan memberikan waktu tambahan belajar untuk siswa, serta kendala dalam mengungkapkan nilai sains dapat ditangani dengan meningkatkan penghayatan bagi siswa untuk lebih memahami materi sistem ekskresi.

\section{SIMPULAN}

Berdasarkan hasil penelitian mengenai penerapan model PjBL bermuatan nilai dapat disimpulkan bahwa terdapat peningkatan pada penguasaan konsep dan sikap siswa. N-gain penguasaan konsep siswa termasuk dalam kategori sedang, rata-rata penguasaan konsep siswa termasuk dalam kategori baik dan persentase jumlah siswa yang berada diatas nilai KKM sebesar (62,85\%). Tingkat penerimaan siswa terhadap nilai sains termasuk pada kategori tinggi dengan tingkat penerimaan nilai sains tertinggi ialah pada variabel nilai religi sedangkan rata-rata sikap siswa berdasarkan hasil observasi termasuk dalam kategori sangat baik. Hasil analisis statistik yang dilakukan menunjukkan bahwa model PjBL bermuatan nilai berpengaruh terhadap penguasaan konsep dan sikap siswa terhadap penerimaan nilai-nilai sains. Adapun hasil perhitungan korelasi statistik menunjukkan bahwa terdapat hubungan korelasi positif dengan kategori rendah. Selama pembelajaran seluruh siswa mengalami kendala dengan kendala yang tertinggi dialami siswa adalah kendala dalam merancang proyek. Dengan demikian pembelajaran model PjBL bermuatan nilai dapat dilaksanakan pada tingkat SMA.

\section{REFERENSI}

Azwar, S. (2010). Penyusunan Skala Psikologi. Yogyakarta: Pustaka Belajar.

Bahruddin. (2007). Teori Belajar dan Pembelajaran. Yogyakarta: Ar-ruz Media.

Dimyati \&. Mudjiono. (2009). Belajar dan Pembelajaran. Jakarta: Rineka Cipta.

Iswadi, H. (2012). Disain Pembelajaran Matematika untuk Generasi Z. [Online]. Tersedia: www.ubaya.ac.id. (Diakses pada tanggal 25 Mei 2014).

Kemendikbud. (2013). Permendikbud No. 8 Tahun 2013 tentang Implementasi Kurikulum. [Online]. Tersedia: https://bit.ly/2xInfGH. (Diakses pada tanggal 25 Mei 2014).

Kesuma, D., Darmawan, C., \& Permana, J.. (2011). Pendidikan Karakter. Bandung: PT Remaja Rosdakarya.

Nugraha. (2013). Masa Depan Indonesia di Generasi Y. [Online]. Tersedia: https://bit.ly/2NIViZj (Diakses pada tanggal 24 Juni 2014).

Rustaman. (2005). Strategi Belajar Mengajar Biologi. Malang: Universitas Negeri Malang

Slameto. (2003). Belajar dan Faktor Faktor yang Mempengarubinya. Jakarta: Rineka Cipta.

Wena. (2008). Strategi Pembelajaran Kontemporer (Suatu Tinjauan Konseptual Operasional. Jakarta: Bumi Aksara.

Yudianto. (2008). Manajemen Alam Sumber Pendidikan Nilai. Bandung: Mughni Sejahtera. 